\title{
Evaluation of the Effect of Different Physico-Chemical Properties of Soil on Modulus of Rupture (MOR)
}

\author{
Minakshi Serawat ${ }^{1 *}$, V. K. Phogat ${ }^{1}$, Asha Serawat ${ }^{2 *}$ and Anil Kapoor ${ }^{3}$ \\ ${ }^{1}$ CCS Haryana Agricultural University, Hisar, Haryana, India-125004 \\ ${ }^{2}$ Swami Keshwanand Rajasthan Agriculture University, Bikaner, Rajasthan, India-334006 \\ ${ }^{3}$ GB Pant University of Agriculture and Technology, Pantnagar, Uttarakhand, India-263145 \\ *Corresponding author
}

\begin{tabular}{|l|}
\hline Ke y w o r d s \\
Modulus of rupture, \\
aggregate stability \\
index, organic \\
carbon content
\end{tabular}

\section{A B S T R A C T}

An experiment on "Evaluation of factors affecting modulus of rupture as an index of crusting in soils of Haryana" was carried out during 2016-17 at Chaudhary Charan Singh Haryana Agricultural University, Hisar, Haryana. The soil samples were collected from 21 locations from farmers' fields in from 0-5 and 5-15 cm depths from different districts of the Haryana having wide range of texture ranging from sand to silty clay loam. The effect of different physico-chemical properties of these texturally different soils was evaluated on their modulus of rupture (MOR) values. The organic carbon, aggregate size analysis, mean weight diameter and modulus of rupture of all the soils were determined using standard methods. The effect of different soil properties on modulus of rupture of soils was evaluated. The MOR of different textured soils at both the depths $(0-5$ and $5-15 \mathrm{~cm})$ was significantly positive and lineally correlated with the soil organic carbon contents of soils with $\mathrm{R}^{2}$ value of 0.74 and 0.75 for $0-5$ and $5-15 \mathrm{~cm}$ depths. The water stable aggregates at 0-5 and $5-15 \mathrm{~cm}$ depths were found significantly positive and linearly correlated with organic carbon content of soils. The water stable aggregates were highest in silty clay loam $(67.42 \%)$ and lowest in sand $(30.85 \%)$ at $0-5 \mathrm{~cm}$ depth. Aggregate stability index as mean weight diameter (MWD) was observed to be higher in fine textured soils as compared to coarse textured soils. The silty clay loam soils were found with highest MWD of $1.61 \mathrm{~mm}$ and $1.54 \mathrm{~mm}$ at $0-5$ and $5-15 \mathrm{~cm}$ depth amongst all the soils respectively. The MOR was found highly dependent on silt + clay and water stable aggregates.

\section{Introduction}

There is growing realization that the deterioration of the soil physical environment is a major reason for decreasing crop productivity. Soil crusting is precursors to surface compaction, low infiltration, and high soil evaporation, particularly in light texture soils of arid and semi-arid regions (Passioura, 1991). The compaction results in increase in bulk density and decrease in hydraulic conductivity. Surface aggregates slake due to the raindrop impact and establish a thin layer of low permeability, low porosity and high density crust due to clogging of pores by dispersed particles. This hard uniform crust 
prevents seedling emergence when dried. Modulus of rupture or tensile strength is an indirect method of measuring soil strength which may be defined as the maximum force per unit area that a material can withstand without breaking. Hillel (1980) defined the tensile strength of soil as the force required for separation or rupture of soil particles.

Various soil properties such as texture, clay mineralogy (Guerif., 1990; Ley et al., 1993), organic matter content (Perfect et al., 1995; Rahimi et al., 2000) and strength of aggregates etc affect the modulus of rupture. Reduction in organic matter, increase in sand content, increase in saturated hydraulic conductivity and poor aggregation leads to the crusting and compaction of soils. Mitigation of the problem of soil crusting requires in depth investigation of the factors responsible for its formation and strength.

\section{Materials and Methods}

A study was carried out at Chaudhary Charan Singh Haryana Agricultural University, Hisar, Haryana during 2016-17. The soil samples were collected from $0-5$ and 5-15 cm depths from 21 different locations from different districts of the Haryana and different soil physico-chemical properties were determined using the following methods:

Mechanical composition was determined by international pipette method as described by Piper (1996). Soil samples were treated with dilute hydrochloric acid and hydrogen peroxide to remove lime and oxides of iron and aluminum and organic matter, respectively. The soil solution were filtered and treated with sodium hexa-metaphosphate to keep the clay particles dispersed. Separation of different size fractions was done by sieving and sedimentation method. Determination of soil organic carbon done by wet digestion method (Walkley and Black,
1934) using the following formula:

SOC $(\%)=[(\mathrm{B}-\mathrm{S}) \times 0.003 \times 100 / 2 \mathrm{x}$ weight of soil] $\times 1.3$

Where,

SOC = soil organic carbon content $(\%)$,

$\mathrm{B}=$ blank reading,

$\mathrm{S}=$ soil sample reading.

The percent organic carbon was multiplied by 1.724 to obtain the content of organic matter.

The water stability of soil aggregates was determined by wet sieving method using Yoder's apparatus (Yoder, 1936). For determination of WSA, air dried aggregates were wet sieved in distilled water in Yoder's apparatus. After wet sieving the mass of stable aggregates is determined. Aggregate stability is expressed as the percentage of stable aggregates of the total aggregates after deduction of sand content.

The aggregate stability index in terms of mean weight diameter (MWD) was calculated from the data of aggregate size analysis for the samples as:

$$
\text { MWD }=\sum_{\mathrm{i}=1}^{\mathrm{n}} \mathrm{d}_{\mathrm{i}} \mathrm{w}_{\mathrm{i}}
$$

Where

$\mathrm{n}=$ number of size fraction,

$\mathrm{d}_{\mathrm{i}}=$ mean diameter of each size range,

$\mathrm{w}_{\mathrm{i}}=$ fraction weight of aggregate in that size range of total dry weight of the sample analyzed.

For the determination of modulus of rupture (Reeve, 1965), the samples were placed in a rectangular briquette mould set on a porous base and saturated with deionised water. After saturation the soil was dried in an oven at $50^{\circ} \mathrm{C}$. The soil briquettes thus made were broken on a breaking machine. 
The dimensions of the briquettes fractured surface were measured and the modulus of rupture was calculated as follows:

$$
S=\frac{3 F L}{2 b d^{2}}
$$

Where

$\mathrm{S}=$ modulus of rupture (dynes $\mathrm{cm}^{-1}$ )

$\mathrm{F}=$ breaking force (dynes) $=$ weight of water $\times 980$

$\mathrm{L}=$ the distance between two lower bars $(\mathrm{cm})$

$\mathrm{b}=$ width of briquette $(\mathrm{cm})$

$\mathrm{d}=$ thickness of briquette $(\mathrm{cm})$.

\section{Results and Discussion}

\section{Effect of soil texture}

The data on mechanical composition of the soil samples collected from different villages revealed that there is a wide range in sand, silt and clay contents in the samples. The soils were found to belong to eight textural classes i.e. sand, loamy sand, sandy loam, loam, silty loam, sandy clay loam, clay loam and silty clay loam.

The modulus of rupture of experimental soils was significantly positive and linearly correlated with the silt + clay contents of soils with $\mathrm{R}^{2}$ (coefficient of determination) value of 0.67 and 0.63 at $0-5,5-15 \mathrm{~cm}$ respectively (Fig.1a and 1b). It indicates that as silt+clay content of soils increases, the inter-particle contact of soil increases which results in linearly increase in modulus of rupture (Kemper et al., 1987).

The modulus of rupture of soils at $0-5 \mathrm{~cm}$ and $5-15 \mathrm{~cm}$ depths was found negatively and linearly correlated with sand content of soils with $\mathrm{R}^{2}$ value of 0.68 and 0.61 respectively. Several studies have shown the positive effect of clay content (Bartoli et al., 1992; Perfect et al., 1995) and negative effect of sand content on soil strength (Perfect et al., 1995). The increase of modulus of rupture with decreasing in sand content and increase in silt+clay content of soil is due to more effect of sand content on the resistance of soil aggregates against application of external forces than the clay content (Mbagwu and Bazzoffi., 1998).

\section{Effect of soil organic matter content}

Mean soil organic carbon of 0-5 and 5-15 cm depths (Table 1) was observed lowest in sand texture soils. The organic carbon content in the surface $5 \mathrm{~cm}$ soil depth was found higher than in $5-15 \mathrm{~cm}$. The results indicated that as the fineness of the texture increased, the organic carbon content also increased but no significant differences were observed in loamy soils except in sandy loam in the surface 0-5 cm depth. Burke et al., 1989 reported that SOC increases with increase clay content in soils.

The MOR for the different textural classes was significantly positive and lineally correlated with organic carbon contents of soils with $\mathrm{R}^{2}$ value of 0.74 and 0.75 at $0-5$ and 5-15 cm depths (Fig.2a and 2b). It indicates that as soil organic carbon content increases, the modulus of rupture increases. But soil organic carbon increases soil aggregation and reduces the soil strength.

It appears that amount of soc in soils of Haryana is not playing role in aggregation to the extent it was expected based of literature. This may be due to low clay content and high temperature in summer and low moisture content almost through the year except few months during monsoon season and winter months. Imhoff et al., (2002) reported that this may be due to a complex relationship between silt+clay and soil OM content. Guerif., 1990; Watts and Dexter., 1998 also found negative correlation between the aggregate strength and organic matter. 


\section{Effect of water stable aggregates}

Results indicated in Table 2 showed that the amount of water stable aggregates were highest in silty clay loam followed by clay loam, sandy clay loam, silty loam, loam, sandy loam, loamy sand and sand at $0-5 \mathrm{~cm}$ depth. Similar trend was observed in $5-15 \mathrm{~cm}$ soil depth. Results showed that statistically there was no difference in water stable aggregates in both the depths in different textured soils. The MOR of texturally different soils was significantly positively correlated with water stable aggregates in pooled depths $(0-5$ and $5-15 \mathrm{~cm})$ with an $\mathrm{R}^{2}$ value of 0.68 (Fig.3a). The results show that as the water stable aggregates increases, modulus of rupture increases as in the present study the water stable aggregates are enhanced upon increase in soil organic carbon resulting in decreasing the pore size. Emerson (1977) suggested that organic matter stabilized the aggregates mainly by forming and strengthening bonds between the particles.

\section{Effect of aggregate stablility}

Aggregate stability index as mean weight diameter (MWD) of different textural soils (Fig.4) was observed to be higher in fine textured soils as compared to coarse textured soils viz. sand < loamy sand < sandy loam < loam < sandy clay loam < clay loam < silty clay loam soils. The silty clay loam soils were found with highest MWD of $1.61 \mathrm{~mm}$ and $1.54 \mathrm{~mm}$ at $0-5$ and $5-15 \mathrm{~cm}$ depth amongst all the soils. In most of the soils, the MWD were observed lower for surface as compared to subsurface layers. The stability of both micro- and macropores depends on the stability of soil aggregates and strength of bonds between different structural units during rain or irrigation (Dexter, 1988). The relationship between modulus of rupture and mean weight diameter or aggregate stability was linear and positive with $R^{2}$ value of 0.37 for (Fig. 3b). This may be due to increase in organic matter. Chenu et al., (2000) and Rachman et al., (2003) observed that greater aggregate stability occurred in soils with higher organic matter.

Table.1 Mean organic carbon (\%) of texturally different soils at 0-5 and 5-15 cm soil depths

\begin{tabular}{|c|l|c|c|}
\hline Sr. No. & Texture & $\mathbf{0 - 5 c m}$ & $\mathbf{5 - 1 5 c m}$ \\
\hline $\mathbf{1 .}$ & Sand & $0.28 \pm 0.06$ & $0.23 \pm 0.03$ \\
\hline $\mathbf{2 .}$ & Loamy sand & $0.54 \pm 0.03$ & $0.46 \pm 0.05$ \\
\hline $\mathbf{3 .}$ & Sandy loam & $0.62 \pm 0.03$ & $0.58 \pm 0.03$ \\
\hline $\mathbf{4 .}$ & Loam & $0.70 \pm 0.07$ & $0.64 \pm 0.07$ \\
\hline $\mathbf{5 .}$ & Silty loam & $0.80 \pm 0.05$ & $0.67 \pm 0.07$ \\
\hline $\mathbf{6 .}$ & Sandy clay loam & $0.74 \pm 0.03$ & $0.52 \pm 0.03$ \\
\hline $\mathbf{7 .}$ & Clay loam & $0.78 \pm 0.03$ & $0.54 \pm 0.01$ \\
\hline $\mathbf{8 .}$ & Silty clay loam & $0.76 \pm 0.02$ & $0.69 \pm 0.03$ \\
\hline
\end{tabular}


Table.2 Water stable aggregates (\%) of texturally different soils at 0-5 and 5-15 cm soil depths

\begin{tabular}{|c|l|c|c|}
\hline Sr. No. & Texture & \multicolumn{2}{|c|}{ Water stable aggregates $\mathbf{( > \mathbf { 0 . 2 5 }} \mathbf{~ m m})$} \\
\cline { 3 - 4 } & & $\mathbf{0 - 5} \mathbf{c m}$ & $\mathbf{5 - 1 5} \mathbf{c m}$ \\
\hline $\mathbf{1 .}$ & Sand & $4.32 \pm 0.49$ & $5.20 \pm 0.50$ \\
\hline 2. & Loamy sand & $30.85 \pm 3.49$ & $32.30 \pm 4.09$ \\
\hline $\mathbf{3 .}$ & Sandy loam & $38.78 \pm 0.19$ & $39.87 \pm 0.17$ \\
\hline $\mathbf{4 .}$ & Loam & $55.32 \pm 1.85$ & $56.66 \pm 1.74$ \\
\hline $\mathbf{5 .}$ & Silty loam & $58.21 \pm 1.00$ & $58.25 \pm 1.99$ \\
\hline $\mathbf{6 .}$ & Sandy clay loam & $64.22 \pm 1.10$ & $64.34 \pm 0.97$ \\
\hline $\mathbf{7 .}$ & Clay loam & $67.01 \pm 0.60$ & $67.12 \pm 1.44$ \\
\hline $\mathbf{8 .}$ & Silty clay loam & $67.42 \pm 1.56$ & $68.42 \pm 0.95$ \\
\hline
\end{tabular}

Table.3 Values of modulus of rupture of texturally different soils at 0-5 and 5-15 cm soil depths

\begin{tabular}{|c|l|c|c|}
\hline \multirow{2}{*}{ Sr. No. } & Texture & \multicolumn{2}{|c|}{ Modulus of Rupture $\left(\mathbf{1 \times 1 0} \mathbf{6} \mathbf{d y n e s} / \mathbf{c m}^{\mathbf{2}}\right)$} \\
\cline { 3 - 4 } & & $\mathbf{0 - 5} \mathbf{c m}$ & $\mathbf{5 - 1 5} \mathbf{c m}$ \\
\hline $\mathbf{1 .}$ & Sand & $0.06 \pm 0.01$ & $0.08 \pm 0.05$ \\
\hline $\mathbf{2 .}$ & Loamy sand & $0.20 \pm 0.05$ & $0.33 \pm 0.10$ \\
\hline $\mathbf{3 .}$ & Sandy loam & $0.56 \pm 0.03$ & $0.89 \pm 0.05$ \\
\hline $\mathbf{4 .}$ & Loam & $1.22 \pm 0.18$ & $1.53 \pm 0.26$ \\
\hline $\mathbf{5 .}$ & Silty loam & $1.40 \pm 0.10$ & $1.61 \pm 0.12$ \\
\hline $\mathbf{6 .}$ & Sandy clay loam & $0.86 \pm 0.04$ & $0.91 \pm 0.03$ \\
\hline $\mathbf{7 .}$ & Clay loam & $0.80 \pm 0.02$ & $1.13 \pm 0.05$ \\
\hline $\mathbf{8 .}$ & Silty clay loam & $1.12 \pm 0.03$ & $1.24 \pm 0.02$ \\
\hline
\end{tabular}

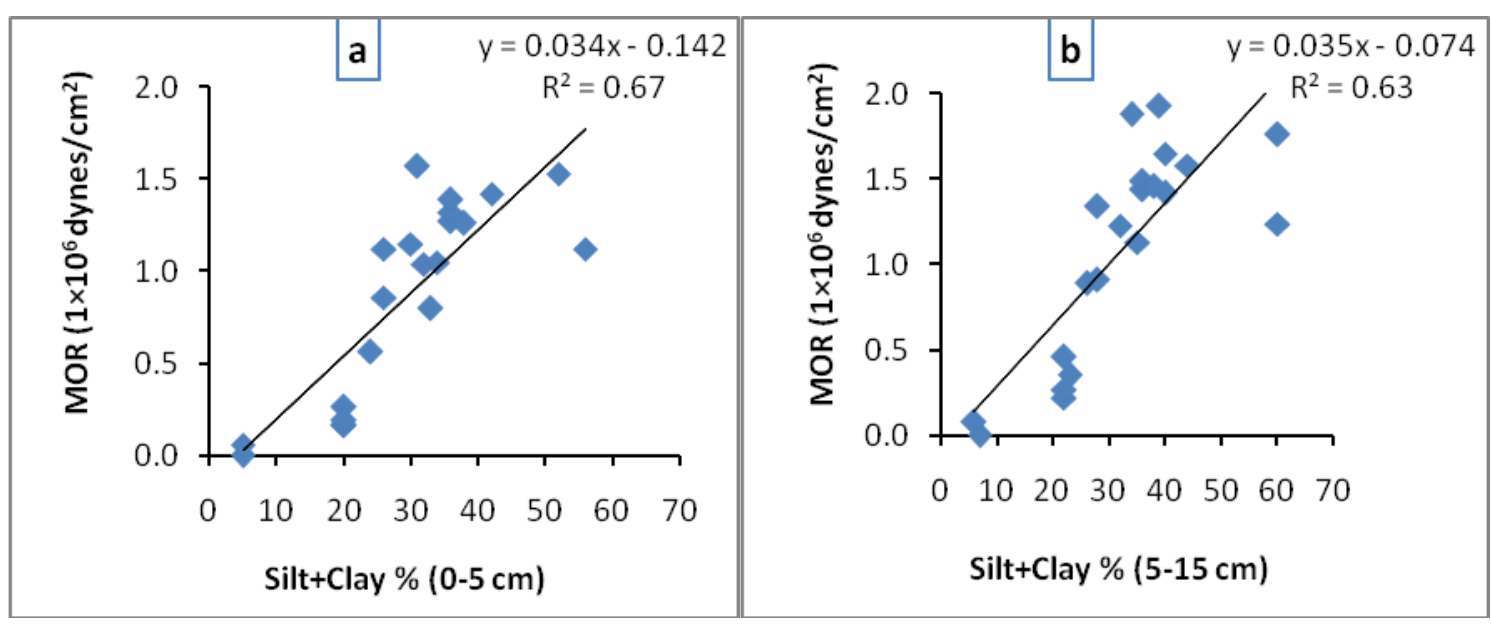

Fig.1 Relationship of Modulus of rupture (MOR) (a) 0-5 cm and (b) 5-15 cm and depths with silt+clay of texturally different soils 


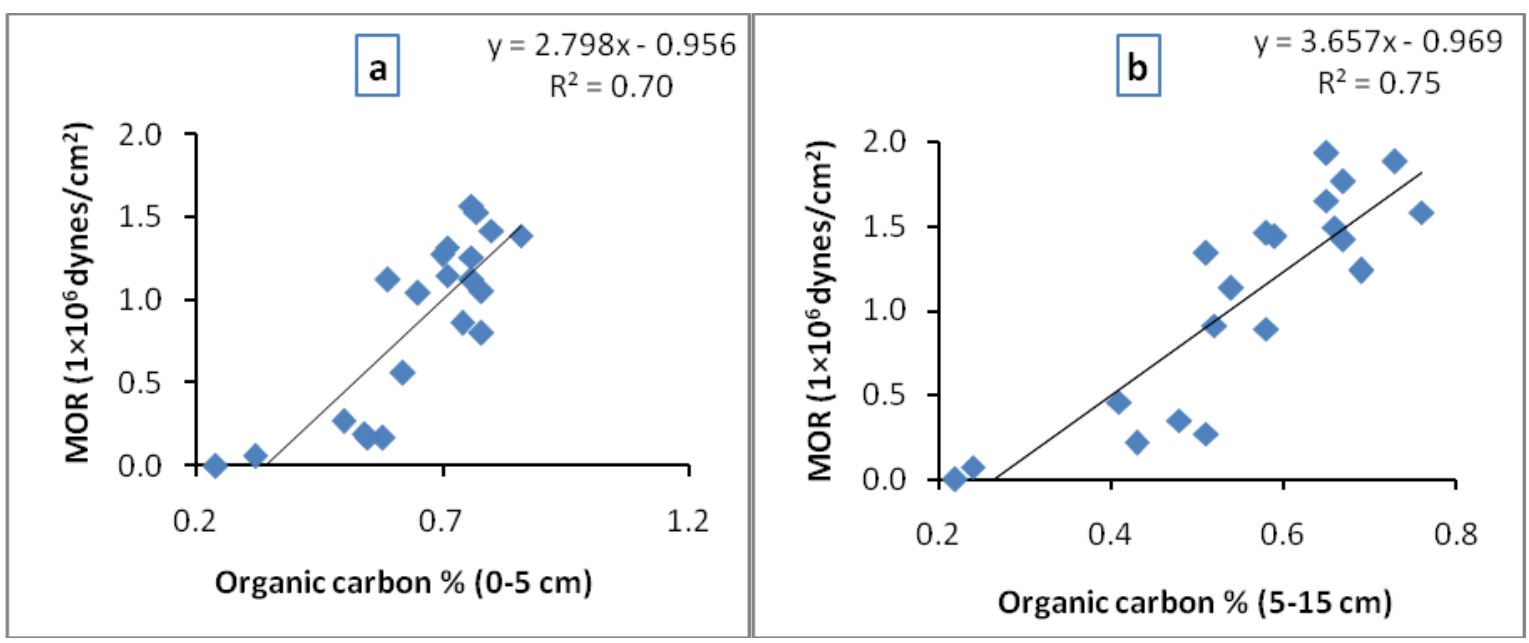

Fig.2 Relationship of Modulus of rupture (MOR) (a) 0-5 cm and (b) 5-15 cm depths with organic carbon of texturally different soils

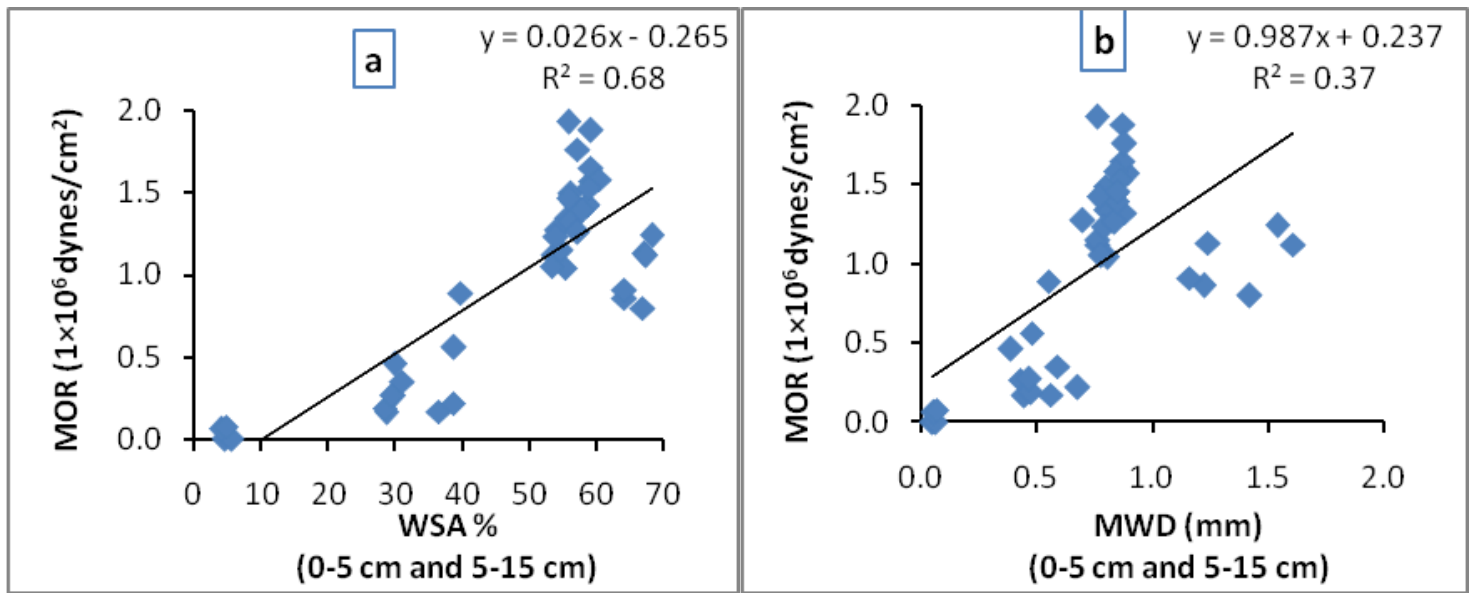

Fig.3 Relationship of modulus of rupture (MOR) with (a) WSA and (b) MWD at pooled depths of 0-5 and 5-15 cm of texturally different soils

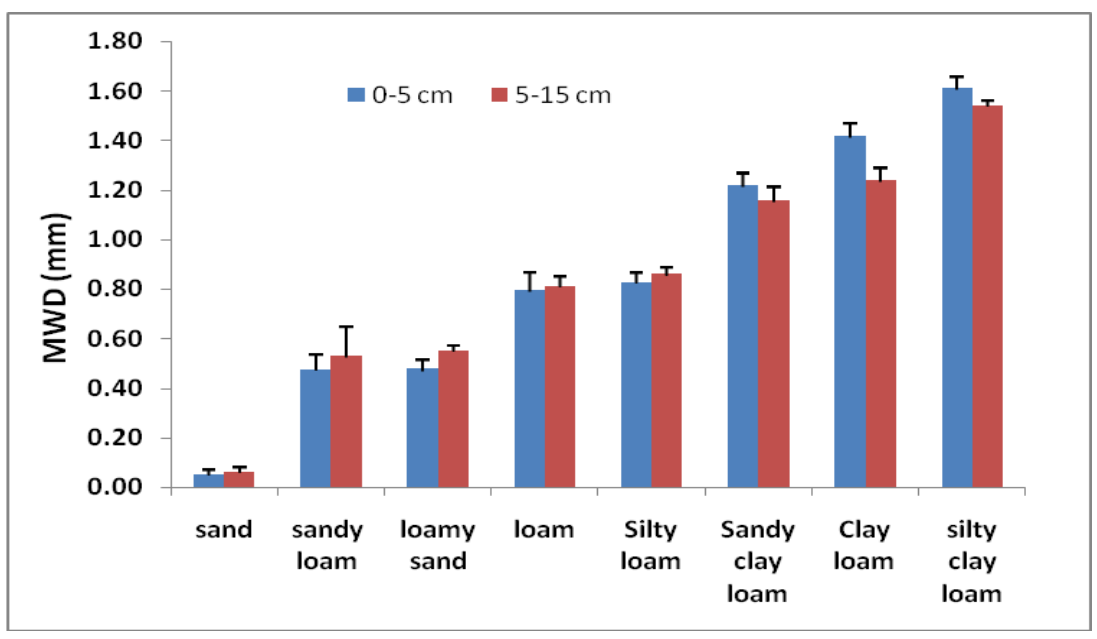

Fig.4 Mean weight diameter of texturally different soils at two depths 
The data on modulus of rupture at various soil depths as influenced by texture are presented in Table 3. The data showed that the values of modulus of rupture increased with increase in fineness of texture from sand to silty loam. At surface $0-5 \mathrm{~cm}$ depth highest modulus of rupture was higher than subsurface $5-15 \mathrm{~cm}$ depth.

This may be due to increase in silt content decrease in saturated hydraulic conductivity of soil with depth. Sarki et al., (2014) reported that the saturated hydraulic conductivity values increase in case of coarse textured soil and decrease in case of fine textured soil.

The Modulus of Rupture different textured soils was significantly positive and lineally correlated with the soil organic carbon contents of soils. The water stable aggregates at $0-5$ and $5-15 \mathrm{~cm}$ depths were also found linearly correlated with organic carbon content of soils. The water stable aggregates were highest in silty clay loam $(67.42 \%)$ and lowest in sand $(30.85 \%)$.

Aggregate stability index was observed significantly higher in fine textured soils as compared to coarse textured soils. The MOR was found highly dependent on silt + clay and water stable aggregates.

\section{References}

Bartoli, F., Burtin, G. and Guérif, J. (1992). Influence of organic matter on aggregation in Oxisols rich in gibbsite or in goethite. II Clay dispersion, aggregate strength and water stability. Geoderma, 54: 259-274.

Burke, I.C., Yonker, C.M., Parton, W.J., Cole, C.V., Flach, K. and Schimel, D.S. (1989). Texture, climate, and cultivation effects on soil organic matter content in U.S. grassland soils. Soil Science
Society of America Journal, 53: 800805.

Chenu, C., Le Bissonnais, Y. and Arrouays, D., (2000). Organic matter influence on clay wettability and soil aggregate stability. Soil Science Society of America Journal, 64: 1479-1486.

Dexter, A.R. (1988). Advances in characterization of soil structure. Soil and Tillage Research, 11: 199-238.

Emerson, W.W. (1977). Physical properties and structure. In J.S. Russell and E.L. Greacen (ed.) Soil factors in crop production in a semi-arid environment. University of Queensland Press, Queensland, Australia. pp.78-104.

Guérif, J. (1990). Factors influencingcompaction-induced increases in soil strength. Soil Tillage Research, 16:167178.

Hillel, D. (1980). Fundamentals of Soil Physics, Academic Press, New York.

Imhoff, S., Silva, A.P. and Dexter, A.R. (2002). Factors contributing to the tensile strength and friability of Oxisols. Soil Science Society of America Journal, 66: 1656-1661.

Kemper, W.D., Rosenau, R.C. and Dexter, A.R. (1987). Cohesion development in disrupted soils as affected by clay and organic matter content and temperature. Soil Science Society of America Journal, 51: 860-867.

Ley, G.J., Mullins, C.E. and Lal, R. (1993). Effects of soil properties on the strength of weakly structured tropical soils. Soil Tillage Research, 28:1-13.

Mbagwu, J.S.C. and Bazzoffi, P. (1998). Soil characteristics related to resistance of breakdown of dry soil aggregates by waterdrops. Soil and Tillage Research, 45: 133-145.

Passioura, J.B. (2002). Soil conditions and plant growth. Plant Cell Environ. 25:311-318.

Perfect, E., Kay, B.D. and da Silva, A.P. 
(1995). Influence of soil properties on the statistical characterization of dry aggregate strength. Soil Science Society of America Journal, 59: 532-537.

Piper, C.S. (1966). Soil and Plant analysis. Hans Publisher, Bombay, 368p.

Rachman, A., Anderson, S.H., Gantzer, C.J. and Thompson, A.L. (2003). Influence of long-term cropping systems on soil physical properties related to soil erodibility. Soil Science Society of America Journal, 67: 637-644.

Rahimi, H., Pazira, E. and Tajik, F. (2000). Effect of soil organic matter, electrical conductivity and sodium adsorption ratio on tensile strength of aggregates. Soil Tillage Research, 54:145-153.

Reeve, R.C. (1965). Modulus of rupture. In "Methods of Soil Analysis," Part 1, ASA Monograph 9, Madison, WI: 466471.

Sarki, A. Mirjat, MS, Mahessar, AA, Kori,
SM., and Qureshi, AL. (2014). Determination of Saturated Hydraulic Conductivity of Different Soil Texture Materials. Journal of Agriculture and Veterinary Science, 7: 56-62.

Walkley, A. and Black, T.A. (1934). An examination of the Degt. Jarett method for determination of soil organic matter and a proposed modification of cromic acid titration. Soil Science, 37: 29-38.

Watts, C.W. and Dexter, A.R. (1998). Soil friability: theory, measurement and the effects of management and organic carbon content. Eur J Soil Sci, 49:7384.

Yoder, R.E. (1936). A Direct Method of Aggregate Analysis of Soils and a Study of the Physical Nature of Soil Erosion Losses. American Society of Agronomy Journal, 28: 337-351.

\section{How to cite this article:}

Minakshi Serawat, V. K. Phogat, Asha Serawat and Anil Kapoor. 2020. Evaluation of the Effect of Different Physico-Chemical Properties of Soil on Modulus of Rupture (MOR). Int.J.Curr.Microbiol.App.Sci. 9(03): 1049-1056. doi: https://doi.org/10.20546/ijcmas.2020.903.123 